\title{
Studies on the Synthesis and Release of Insulin from the Beta Cells of Pancreatic Islets
}

\section{Sadayoshi YOKOH and Kentaro OKUMURA}

Department of Medicine, Kyoto Prefectural University of Medicine, Kyoto, Japan

The mechanism of insulin synthesis and release from pancreatic beta cells was investigated in rabbits. Islets of Langerhans were observed by light and electron microscopy. Serum insulin levels and extractable insulin content of pancreas were measured by dextran coated charcoal immunoassay.

Results

a) Rabbits being starved for 10 days: Blood sugar levels and serum immunoreactive insulin (IRI) showed the decreasing tendency during starvation. Extractable insulin from pancreas gradually fell toward a half of pre-starved levels on the 10th day. On the same day of starvation, beta cell nuclei became smaller and beta granules almost disappeared in aldehyde thionin staining. In electron microscopy, striking characteristic of these beta cells was the appearane of a large number of empty sacs almost same sized as limiting membranes of beta granules. Golgi complex was lacking in dilatation and vacuolation of its membranes and premature granules were absent.

b) Rabbits injected intramuscularly with lente insulin of $2 \mathrm{U} / \mathrm{kg}$ for 3 months: $\mathrm{Re}-$ markable degranulation of beta cells in light microscopy, and constriction of Golgi complexes accompanying with disappearance of premature granules, appearance of a large number of empty sacs with significant decrease of beta granules in electron microscopy, were observed.

c) Rabbits administered with glycodiazin at a dose of $100 \mathrm{mg} / \mathrm{kg} /$ day for $2-9$ months: Maximal rise in serum IRI levels was observed within 3 months and then gradual decrease continued until 9th month. Extractable insulin from pancreas decreased to about a half of the levels prior to administration. In electron microscopy, significant decline of beta granules were recognized but accumulation of empty sacs in cytoplasm were not observed. Golgi complexes were more extensive, showed a higher incidence of dilatation of their lammelle and a larger number of premature granules.

d) Rabbits fed with high carbohydrate diet for 3 days or droppingwise injected with $10 \%$ glucose solution for $6-8$ hours both after 10 days starvation: Regranulation of beta cells in light microscopy, reappearance of cored beta granules, prominent endoplasmic reticulum and well developed Golgi complexes accompanying with many premature granules in electron microscopy were observed in the pancreatic islets of high carbohydrate diet feeding rabbits. But the pancreatic beta cells from glucose injected animals after starvation did not show any reactivation by glucose injection. 


\section{Summary and Conclusion}

The data are summarized as follows. The lack of insulin demand such as starvation or insulin administration bring on the significant decline in insulin synthesis despite the slow releas of insulin from beta cells. On the other hand, glycodiazin administration or high carbohydrate diet feeding after starvation accelerate both synthesis and release of insulin in beta cells. On the basis of these findings, the following hypothesis about insulin secretion is proposed. Insulin or insulin precursor synthesized at the site of endoplasmic reticulum might be condensed to mature beta granules through the form of premature granules in close connection with Golgi complexes. Responding to insulin demand, beta granules would become soluble and oozeout into the cell sap through the limiting membranes of granules. Insulin excluded in cytoplasm might be released into capillary (diacrine type of secretion, not emiocytosis). Then limiting membranes of granules would remain in cytoplasm as empty sacs. They would be utilized rapidly for insulin synthesis in active beta cells, but in inactive beta cells they would remain longer in cytoplasm.

(pp. 728 732) 


\begin{tabular}{llll}
\hline シソポウム II & インスリン分泌の機構と調節 \\
\hline
\end{tabular}

\section{3.インスリンの生成と放出}

\begin{tabular}{ccc}
\multicolumn{2}{l}{ 京都府立医科大学吉田内科 } & \\
横 尾 & 定 & 美 \\
奥 村 & 賢 太 & 郎
\end{tabular}

緒

言

インスリンの生成と放出とは萃ラ氏島 $\beta$ 細胞で行なわれていととは疑ない事実である。乙の二つの働きが, 生体の中では一つの分泌機能として極めて連続的，有機的に遂行されているわけであるが，われわれは実験 成績を解析する上での混乱を避ける意味で，生成と放出を一応概念的に区別して考へる必要があるものと思 つている．何故ならば，Haist も指摘しているように， $\beta$ 細胞の脱顆粒ということを取り上げてみても，て の現象は顆粒放出の促進によつても，又顆粒生成の低下によつても起りうると考えられる．従つて $\beta$ 細胞 における正常な顆粒の分布乃至貯臟は，生成と放出のバランスの上に成り立つと考へられるからである.

てのような前提の下に $\beta$ 細胞のインスリン分泌を観察しょうとするとき，問題となるのは $\beta$ 顆粒の他の細 胞内小器官の態度ならびに血中と膵抽出インスリン量である。われわれはこの点に注目しながら, 家鬼に一 定の条件を負荷するととによつて，膵ラ氏島に強いゆさぶりをかけ，その時の $\beta$ 細胞の態度とインスリン量 よりインスリン分泌機構の一端を解明しようと試みた。

\section{実験動物及び実験方法}

実験動物は体重 $2.5 \mathrm{~kg}$ 前後の雄性家鬼を用い，乙れらは次の如き条件を負荷した。即ち第 1 群は水のみ 自由に与へて 10 日間絶食としたもの. 第 2 群は lente insulin 2 単位 $/ \mathrm{kg}$ 体重を 3 ケ月間筋注したもの. 第 3 群は glycodiagin 1 日 $100 \mathrm{mg} / \mathrm{kg}$ 体重経口投与 $2 \sim 9$ ケ月のもの. 第 4 群は絶食 10 日後含水炭素豊富食 を 3 日間投与したもの. 第 5 群は $10 \%$ ブドー糖を 1 分間に 4 滴の割合で 6 時間点滴静注したもの. 第 6 群は 絶食 10 日後 $10 \%$ ブドー糖を同様の速度で 8 時間点滴静注を行なつたものである.

形態学的研究方法としては，主として aldehyde thionin 染色による光学顕微鏡的観察わよびわれわれの 方法によつてラ氏島の microdissection を行なつた材料についての電子顕微鏡的観察である．その他ラ氏島 の螢光顕微鏡的観察, Ferritin 抗体法による観察等も行なつた。

一方上記実験動物の血糖の推移を追及すると共に，血清インスリンおよび膵抽出インスリンを dextran coated charcoal immunoaisay によつて immunoreactive insulin（以下 IRI と略省）として測定した.

\section{実 験 成 績}

\section{1）正常家兔ラ氏島について}

正常家鬼の膵ラ氏島については己に多くの報告があり，詳細は省略するが， $\beta$ 細胞は $\alpha$ 顆粒より一層高い 電子密度を有する芯 (core) をもつた $\beta$ 顆粒を有し，且つ芯と顆粒限界膜との間の所謂 lucent space が $\alpha$ 顆粒のそれより币広い点で $\alpha$ 顆粒と異る. 又 $\beta$ 細胞の核周团, 時として細胞質内に微細な線維嵄構造（fine fibrous material, filament) を有する点で $\alpha$ 細胞との鑑別が一見して可能である.

家鬼ラ氏島を FITC 標識抗牛インスリンモルモット抗血清で染色し, 螢光顕微鏡で観察すると $\beta$ 細胞に は做漫性に強い特異螢光が認められ， $\beta$ 細胞の免疫反応性インスリンの存在を示していた。 又 Ferritin 抗 
体法で $\beta$ 細胞を電顕的に観察すると， $\beta$ 細胞の膜構造に一致して ferroglobulin の鈎着が認められたが，核 周囲の filament そは ferroglobulin の存在は見られなかつた。

一方インスリンは亜鉛と結合するてとにより不溶性となつて $\beta$ 顆粒として貯蔵されると考へられているが, ての点につき検討する目的で Zim の大塚変法によつて電顕的に観察してみた。亜鉛の局在を示すと考へられ る銀粒子は微細な grain から droplet に至るまで， $\beta$ 顆粒に限局して証明された。 $\beta$ 細胞の細胞質内にも 極く微細な銀粒子の存在が少量みられたが，乙のものの局在の特異性については今後の検討に待ちたい.

2）絶食家鬼について

i ）絶食家鬼の血糖は絶食前に比して稍々低下の 傾向が認められたが有意とは考へられなかつた．血 清インスリン (IRI) も稍低下の傾向を認める程度 にすぎない，一方膵抽出 IRI は日時の経過と共に 減少し, 絶食 10 日目では絶食前值の約 $1 / 2$ の值を示 した. とのことは正常家鬼のラ氏島 $\beta$ 細胞の insulin reserve の大きいととを物語つている. (Fig. 1)

ii）絶食 3 日目のラ氏島 $\beta$ 細胞は aldehyde thionin 染色では正常のものと略々変化が認められず, $\beta$ 顆粒の保存も良好である。電顕的にも $\beta$ 顆粒はよ く保存されているが, Golgi 装置の発達は良好々思 われず，正常 $\beta$ 細胞 Golgi 野にしばしば見られる 所謂 premature granule (pregranule, satellite

Fig. 1. Blood sugar, serum IRI and extracted pancreatic insulin concentration during fasting states

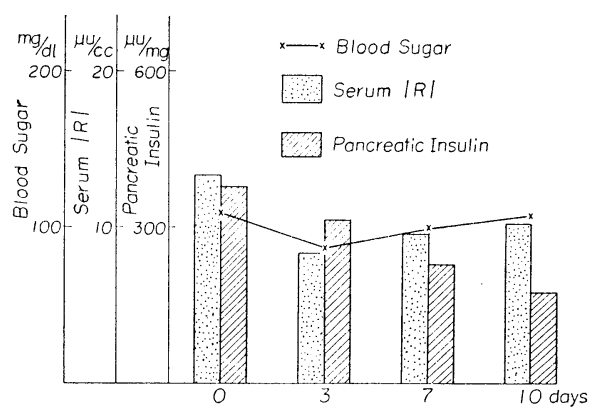
body）は殆ど認められなかつた。

絶食 10 日となると家鬼の体重は $2 / 3$ 以下に減少するものが多く，中には䈣死するものがある．乙の時期の 光顕像では $\beta$ 細胞核は縮少の傾向が見られ， $\beta$ 顆粒は湖漫性に明らかな減少を示す．電顕的には， $\beta$ 顆粒は 芯をもつたものが極めて著明に減少し，その代りに芯の電子密度の低下した顆粒および芯が消失したあとの 顆粒限界膜と考元られる empty な smooth membranous sac (empty sac) が多数出現してくる. ての empty sac は細胞周辺殊飞細胞膜に接して存在するとは限らない,一方 Golgi 装置は僅かの vacuole と vesicle より成るものが多くなり, premature granule も全く認められなくなる. 又疎面小胞体も正常に比し て不著明となり, lysosome like body もしばしば認められるようになる。

\section{3) lente insulin 投与家鬼について}

lente insulin 1 日 2 単位 $/ \mathrm{kg}, 3$ ケ月間筋注した家鬼ラ氏島では, aldehyde thionin 染色で $\beta$ 細胞の顆 粒は濔漫性に強く減少する。電顕的にも芯を有する $\beta$ 顆粒は殆ど認められず，僅かに散見される程度であ る.そして絶食時の $\beta$ 細胞に見られたと同様の所謂 empty sac が多数出現してくるのが見られた。 又 $\beta$ 細 胞の Golgi 装置の発達がわるく, premature granule は殆ど全く認められなかつた。 ての場合も mitochondria の増加を思わせる所見を得たが， 疎面小胞体は保存され正常 $\beta$ 細胞のそれとの比較は困難であつ た.

以上の如き絶食或はインスリン投与という内因性インスリン需要の低下を来たすような条件下にわいても， 糖新生, 肝糖放出等による血糖維持機構の発動と基礎分泌としてのインスリンの緩除な放出が $\beta$ 顆粒の減少 を来したものと考へられる．とのととは絶食中の血清 IRI に著変なく，膵抽出インスリンが著明に減少し たことからも明らかである。

一方 Golgi 装置の発達も不充分で, premature granule の存在が殆ど認められなかつたととは, インス リン生成の低下を示すものと考へたい. 又 empty sac の著しい増加は, 可溶性となつた顆粒がその限界膜 を通つて細胞質へ，更に細胞間隙，毛細管へと放出される所謂 diacrine 形式による顆粒分泌の名残であろ う。そしてての empty sac がインスリン需要の低下した inactive $\beta$ cell に多く見られるととは，インス 
リン生成が低下している為利用されず，長く細胞質内に止つているものと推定される.

\section{4) glycodiazin 投与家鬼について}

抗糖尿病剂 glycodiazin はラ氏島 $\beta$ 細胞に刺激的に作用するてとによつて血糖低下作用を発揮するとさ れる. この glycodiazin を1日 $100 \mathrm{mg} / \mathrm{kg}$ 径口投与した家鬼てついて述べる.

i ) glycodiazin 投与後の血糖は比較的大きな変 動を示し乍らも全体として低下する。乙の間の血清 IRI は投与後 3 ケ月まで漸次上昇したが，以後やや 減少の傾向を示した。 又膵抽出 IRI は glycodiazin 投与後漸次減少し， 6 ケ月では前値の約 $1 / 2$ 亿減少 した. 即ち glycodiazin 投与によつて $\beta$ 膵細胞より のインスリン放出は可成り著明に六進すると同時 に， $\beta$ 細胞のインスリン貯蔵も減少することは明ら かである。(Fig. 2)

ii ）glycodiazin 投与後 2 ケ月で, 光顕では $\beta$ 顆 粒は明が減少し，所謂 patchy type の脱顆粒を 来した. 電顕では $\beta$ 顆粒は多くの $\beta$ 細胞で明かに減

Fig. 2. Blood sugar, serum IRI and extracted pancreatic insulin concentration during glycodiazin administration to rabbits

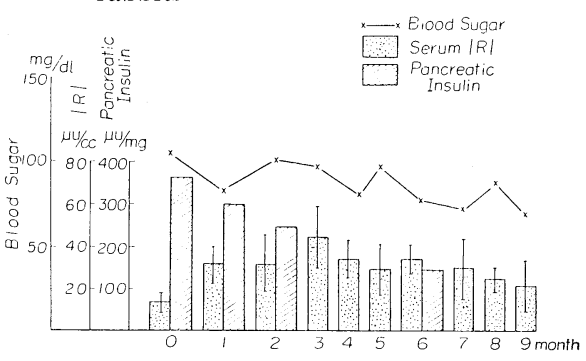

少していたが，前述の絶食又はインスリン投与時の

如き empty sac の異常な増加は全くみられなかつた。 $\beta$ 細胞のあるものでは猶かなりの顆粒か残存し，光 顕で見られた patchy type degranulation と一致する所見と思われた.

ての場合の Golgi 装置は良好な発達を示し, Golgi 野には多くの premature granule が認められた. $\beta$ 細胞ではその他乏トコンドリアの増加がみられたが， $\alpha$ 細胞には変化は認められなかつた。

\section{5）絶食後含水炭素豊富食投与家兔のラ氏島}

絶食 10 日後含炭豊富食を 3 日間投与した家鬼ラ氏島光顕像では $\beta$ 顆粒は再び強く出現し，類洞腔に面して 集合する傾向を示した (patchy type)。電顕的観察によれば， $\beta$ 顆粒は芯を持つたものが略正常に出現し， 良好な発達を示した Golgi 野には，premature granule の出現がみられ，疎面小胞体も層状に発達する像 が見られた。

以上 glycodiazin 投与および絶食後含炭豊食投与の場合，光顕的には所謂 patchy type の顆粒分布が おこり，電顕的には $\beta$ 顆粒の減少（絶食家鬼に含炭豊富食投与の場合は顆粒の増加）および Golgi 装置の 発達と premature granule の出現又はその増加, 時に優性な蹯面小胞体の出現等 active $\beta$ cell を想定さ せる所見が得られた。ことにての場合, empty sac 即ち $\beta$ 顆粒のねけがらともいうべきものが，顆粒の減少 にも拘らず増加しなかつたてとは注目される。即ち顆粒放出後の限界膜はインスリン生成の元進によつて, その為に利用されたという可能性がある。

又 glycodiazin 投与の場合, 血清 IRI が明が増加し, 膵抽出インスリンが減少するととは, 貯蔵イン スリンの放出があつたてとは勿論であるが，投与数ケ月後に猶正常より高い血清 IRI 值を維持していたて ては，インスリン生成の充進を示している。

\section{6) ブドー糖投与家兔について}

i ) 正常家鬼に $10 \%$ ブドー糖を 1 分間 3 滴の速度で点滴静注を行なうと, 点滴開始後 60 分で血糖は plateau 亿達し, 以後 6 時間まで $370 \sim 380 \mathrm{mg} / \mathrm{dl}$ を維持する。一方血清 IRI は 6 時間まで漸次上昇し, 正常 家鬼ラ氏島 $\beta$ 細胞の insulin reserve 即ち生成と放出を含めて余裕の大きいととを物語つている。 (Fig. 3)

次に10日間絶食後の家鬼に同様のブドー糖点滴を行なうと, 血清IRI は殆ど増加が見られず，血糖は極め て急激に上昇し， 3 時間で $700 \mathrm{mg} / \mathrm{dl}$ 以上となり, 以後その值を維持する. てれは 10 日間の絶食によつてラ 氏島 $\beta$ 細胞の insulin reserve が殆ぞ底をついたととを示すと同時に, 前述のような絶食後の $\beta$ 細胞にとつ ててのような急激な異常高血糖は決してインスリン生成への trigger とならないととを示している. (Fig. 4) 
Fig. 3. Blood sugar and serum IRI levels during $10 \%$ glucose dropping injections to rabbits

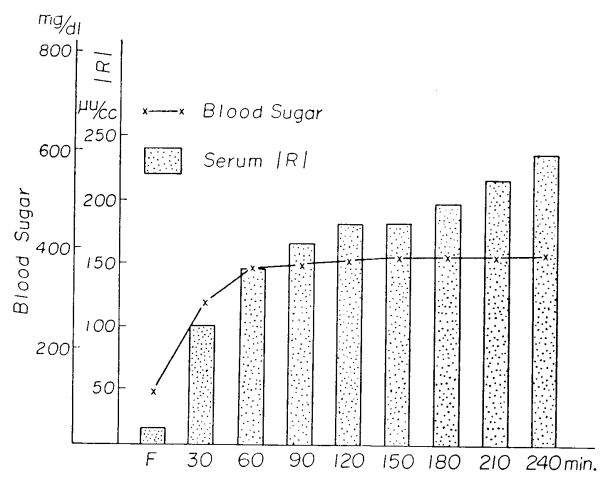

Fig. 4. Blood sugar and serum IRI levels during $10 \%$ glucose dropping injections to 10 days fasting rabbits

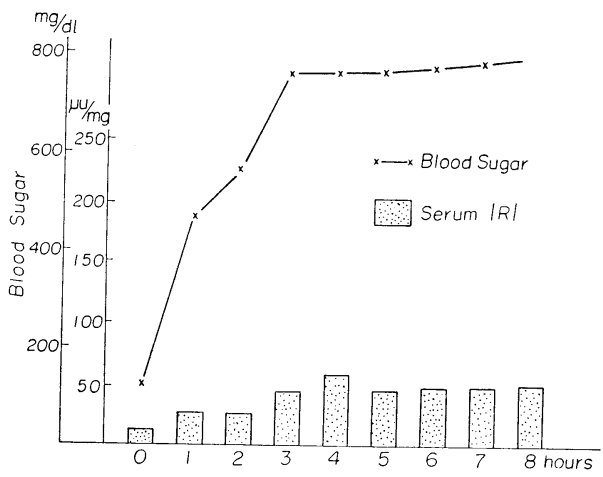

ii ）絶食後ブドー糖点滴静注を行なつた場合の膵ラ氏島は最初意図したような $\beta$ 細胞の刺激像即ち含水炭 素豊富食による絶食後の $\beta$ 細胞の賦活といつた所見は全く認められなかつた. 絶食によつて insulin reserve も少く機能の低下した $\beta$ 細胞にとつて，10\%ブドー糖点滴というような異常高血糖を斉す条件は生理的な範 囲を逸脱した刺激として作用するのかも知れない。

\section{総 括 と結 論}

絶食10日間又はインスリン投与等のインスリン需要の低下を示す条件の負荷によつて $\beta$ 細胞が inactive となつた場合， $\beta$ 細胞からのインスリンの緩除な放出は続くけれども，インスリンの生成は低下すると考へ られる。一方 glycodiazin 投与又は絶食後含炭豊富食投与等はインスリンの放出と共に生成をも六進せし めるものと考へられる.

さて $\beta$ 細胞の活性判定の規準的事項として Haist は光顕的には核の肥大, 脱顆粒の様式, Golgi 装置の negative image 等をあげ, 電顕的には Golgi の発達状態, ribosomal grouping, $\beta$ 顆粒の減少等をあげて いる. 細胞の活性を形態の上から判断するととは極めて慎重を要すると考へられるので, われわれは先人の 意見を参考とし. 今回の実験で試みた二つの条件即ち $\beta$ 細胞の刺㦸時と静止時における変化から, 血中 IRI 及び萃抽出 IRI を裏付けとして次の如き分泌様式 を考へている.

$\alpha$ 細胞では顆粒膜が細胞膜と融合し，その部に幅 広い間隚を生じて顆粒の芯が basement membrane を通つて血管内に放出される所謂 emiocytosis 形式 による分泌像を捉えることは比較的容易である。然 し $\beta$ 細胞では細心の注意にも拘らずてのような形式 による顆粒の放出を捉えることは出来なかつた，従 つてわれわれは Lacy の提唱した emiocytosis 形式 による $\beta$ 顆粒の放出に対しては極めて否定的であ る. $\beta$ 顆粒の放出は前述の所見でも強調したよう に，顆粒の芯が soluble となり顆粒限界膜を通つて 細胞質更に細胞外へと放出される diacrine 形式に よるものと考へられる. そしててのような放出様式 が緊急のインスリン需要に応じうる為にも有利なの

Fig. 5. Mechanism of beta cell secretion

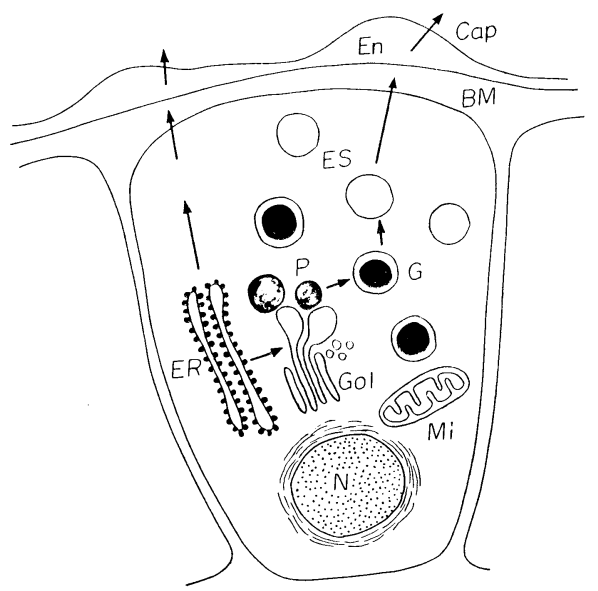


ではあるまいか。このような考へ方を基礎として，われわれの考へているインスリン分泌いついての仮説を シェーマで示すと Fig. 5 の如くである. 即ち疎面小胞体で生成されたインスリンはその前駆物質は Golgi 装 置と極めて密接な協力の下に，恐らくGolgi 膜を通つて Golgi 空胞に入りてれが千切れて premature granule となりやがて $\beta$ 顆粒へと貯蔵される.そしてインスリン需要に応じて可溶性となり, 細胞質中に出, 血管内へ放出される. あとに残つた顆粒限界膜即ち empty sac は再び何らかの形でインスリン生成に利用 される. active $\beta$ cell ではこの cycle の回転が早い為 empty sac として細胞膜に見られなくなるが, inactive $\beta$ cell では cele の回転がおそいため長く細胞質に止ると推定される. 蹯面小胞体で生成されたイ ンスリンが顆粒として貯蔵されるととなく，そのまま細胞外へ出てゆく放出形式もあつてよいと考へられる が，その証明は今後の検討にまたねばならない。

終りに本シンポジゥム参加の機会を与えられた指導教授吉田秀雄会長と座長黒住一昌教授に深謝致します. 又日夜努力を惜しまれなかつた協同研究者の諸兄に感謝致します。

$$
\begin{array}{r}
\text { 協同研究者, 青地 修, 松野瑞賢, 阿部 信行, 藤井 正道 } \\
\text { 木村 浩久, 油谷 桂郎, 河野勝之祐 }
\end{array}
$$

質 問：広大解剖 藤田 尚男 Golgi 装置が活性を帯びるとか静止しているとかを判定する根拠は.

応答: 京府医大吉田内科 横尾 定美 私達は少くともラ氏島 $\beta$ 細胞では Golgi sac の拡大, vesicle の增数殊に所謂 premature granules sat ellite bodies の出現等の所見をむつて, Golgi 装置の機能状態 を推定している. Logothetopoulos は Golgi の ‘inactivity’ と云う言葉を用いているが, active と云う 言葉がわるければ prominent と云つてあよいと考える。 


$$
\text { 横 尾, 奥 村 論 文 付眓 (その1) }
$$

Fig. 1. Electron microscopic histochemistry of zinc in the pancreatic beta cell from normal rabbit. (Zimm-Otsuka's method). Zinc sharply localize just only beta granules as droplets or grains. Zn : zinc, F : filament, $N$ : nucleus $\times 50,000$

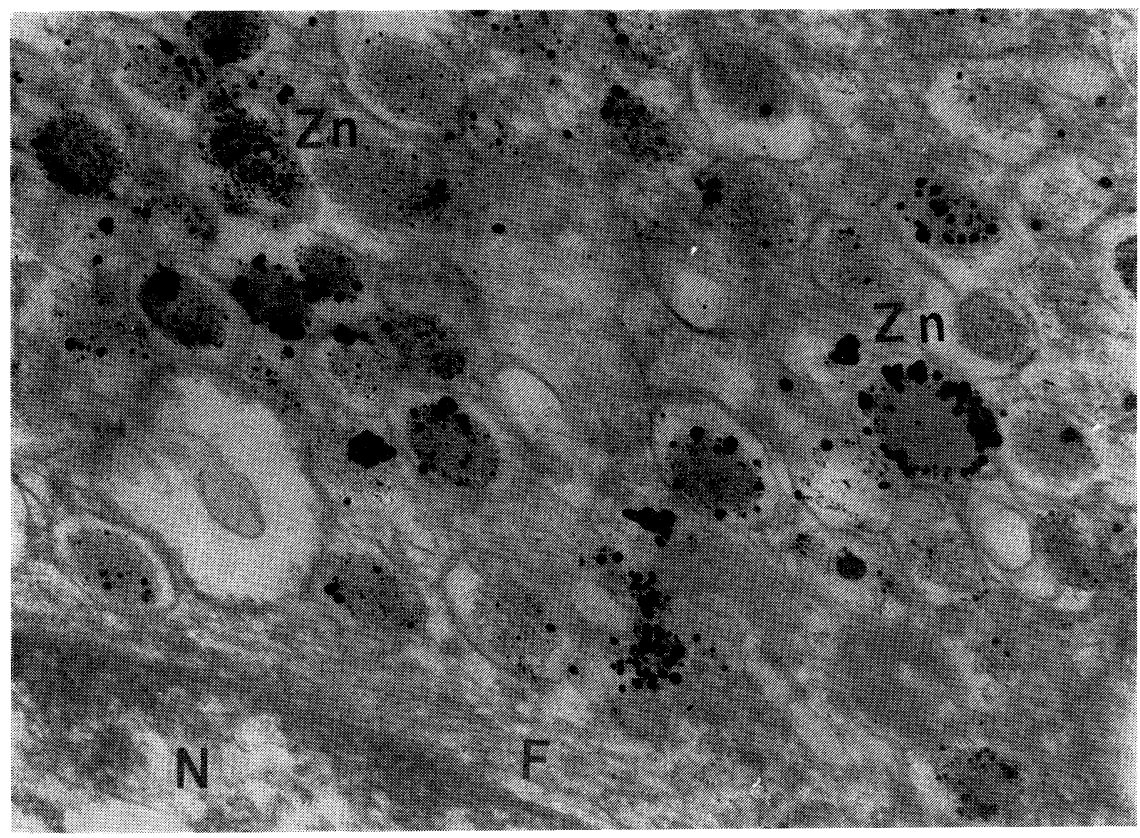

Fig. 2. Electron micrograph of high magnification of the same beta cell. Zn : zinc, $\times 66,000$

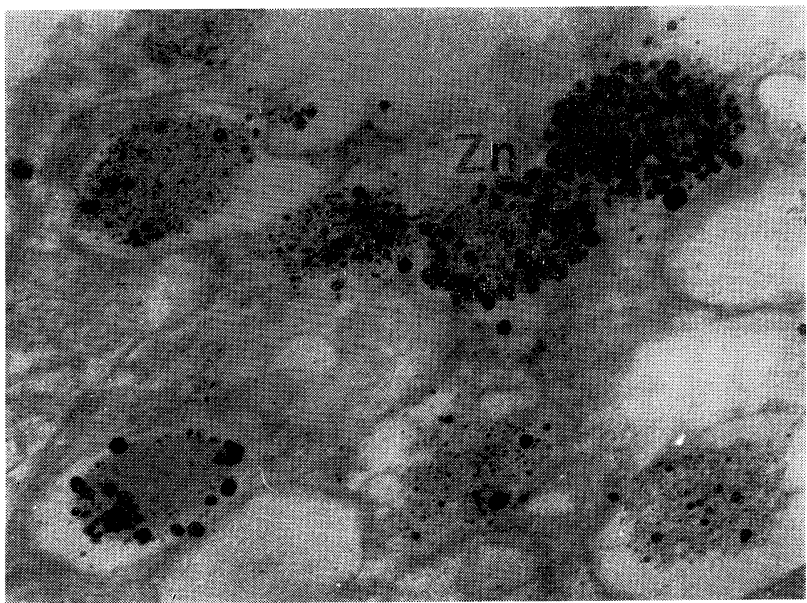


Fig. 3. Electron micrograph of a portion of a beta cell treated with ferritin antibody technique. Ferroglobulin particles attach to the membrane sytem of beta cell. Fe : ferroglobulin, F : filament, $\mathrm{N}$ : nucleus $\times 40,000$

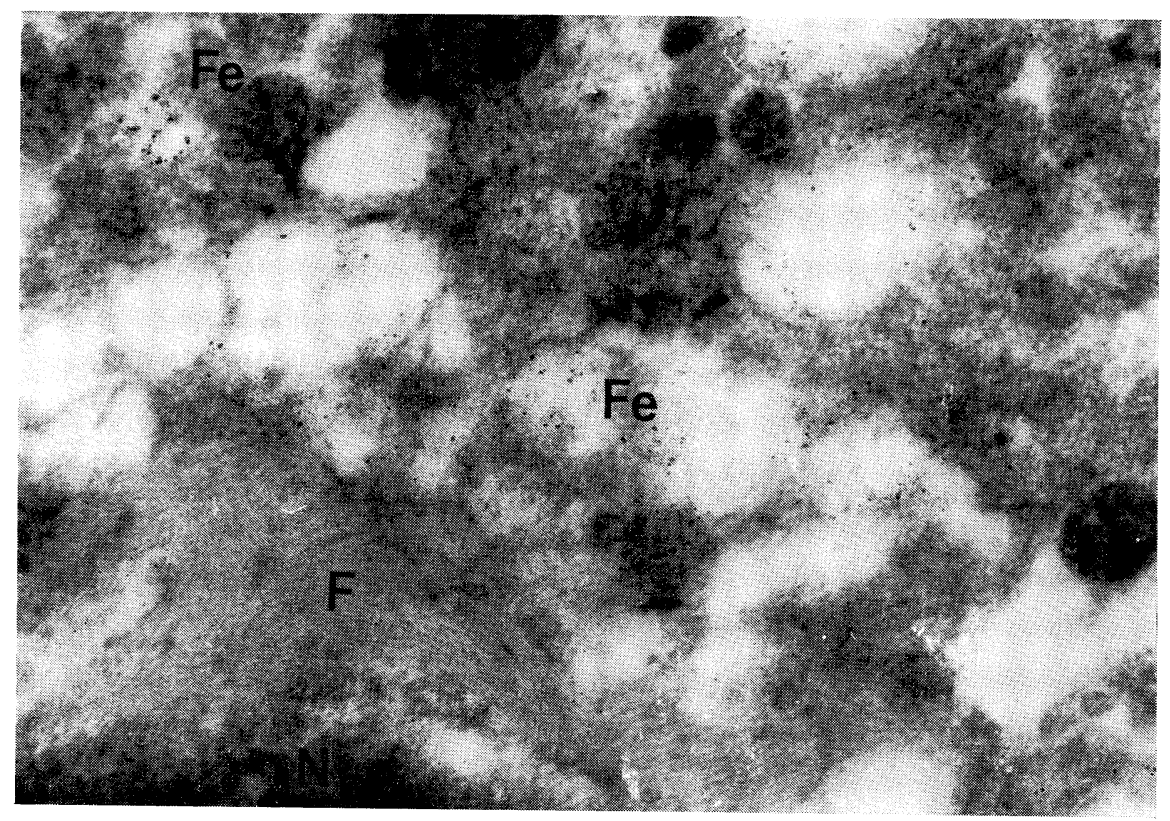

Fig. 4. Electron micrograph of a portion of a beta cell from 3 days starved rabbit showing pretty well developed Golgi apparatus without premature granules. Gol : Golgi apparatus, $\mathrm{N}$ : nucleus, $\mathrm{N}$ : nucleus, $\mathrm{F}:$ filament $\times 19,200$

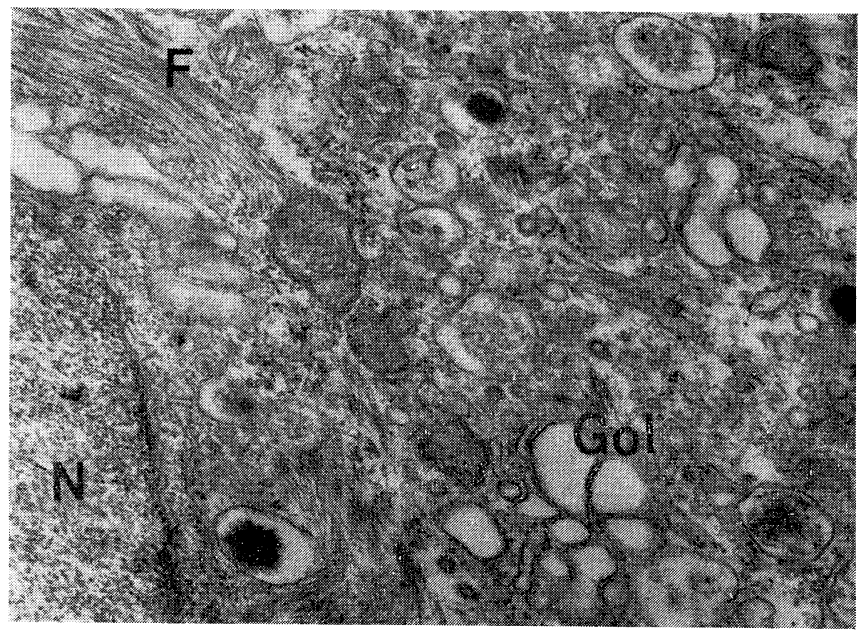




\section{横 尾，奥 村 論 文 付 図（その3)}

Fig. 5. Electron micrograph of a portion af an inactive beta cell (11 days starvation) showing mitochondria and less developed Golgi apparatus. F : filament, M : mitochondria $\times 30,000$

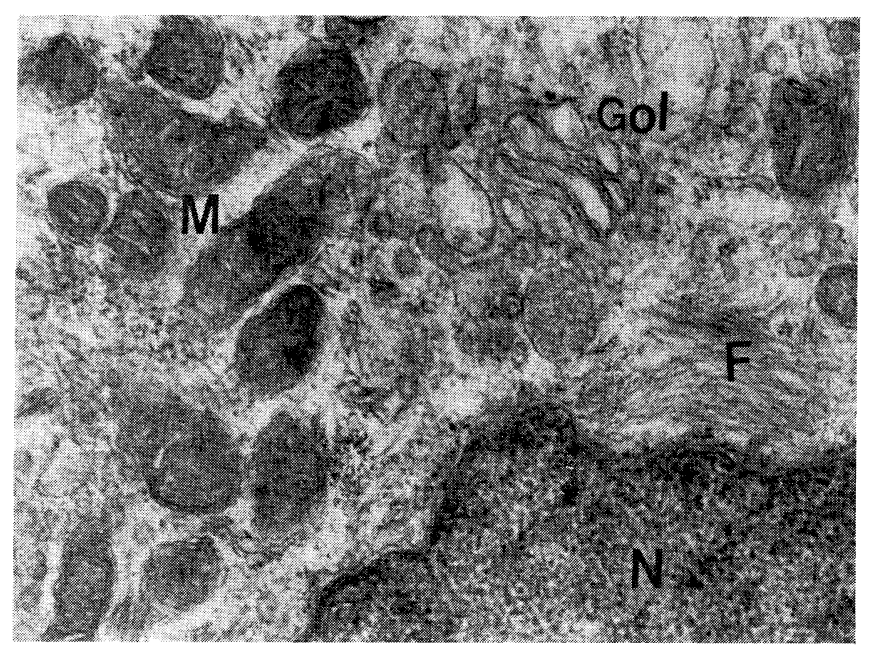

Fig. 6. Electron micrograph of a portion of an imactive beta cell (lente insulin 3 months injection) showing aboundant empty sacs in beta cell cytoplasm. $\mathrm{N}$ : nucleus, $\mathrm{M}$ : mitochondria $\times 12,500$

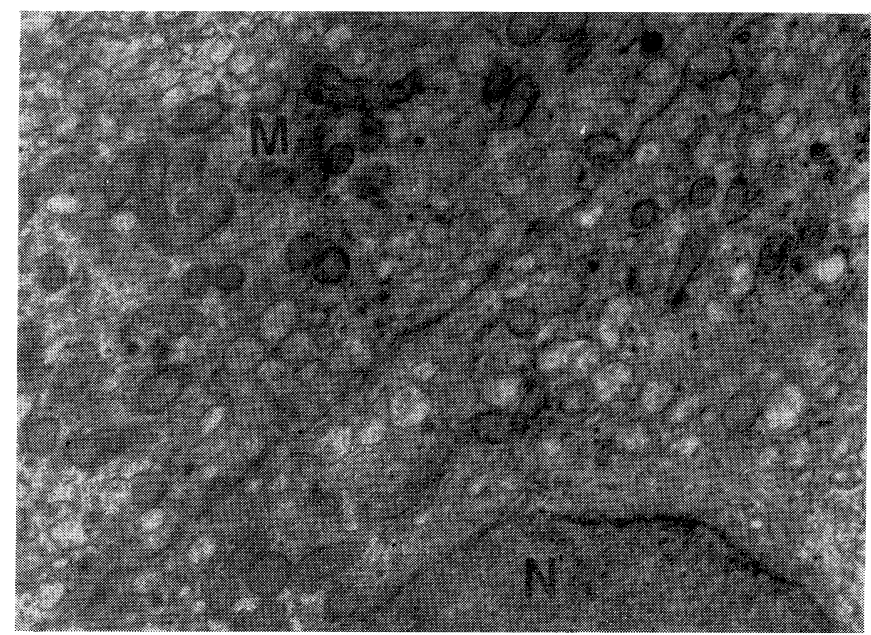




\section{横 尾，奥 村 論 文 付 図（その4)}

Fig. 7. Electron micrograph of an active beta cell (glycodiazin 2 months) showing well developed Golgi area and aboundant mitochondria. Gol : Golgi apparatus, F : filament, $\mathrm{N}$ : nucleus $\times 18,000$

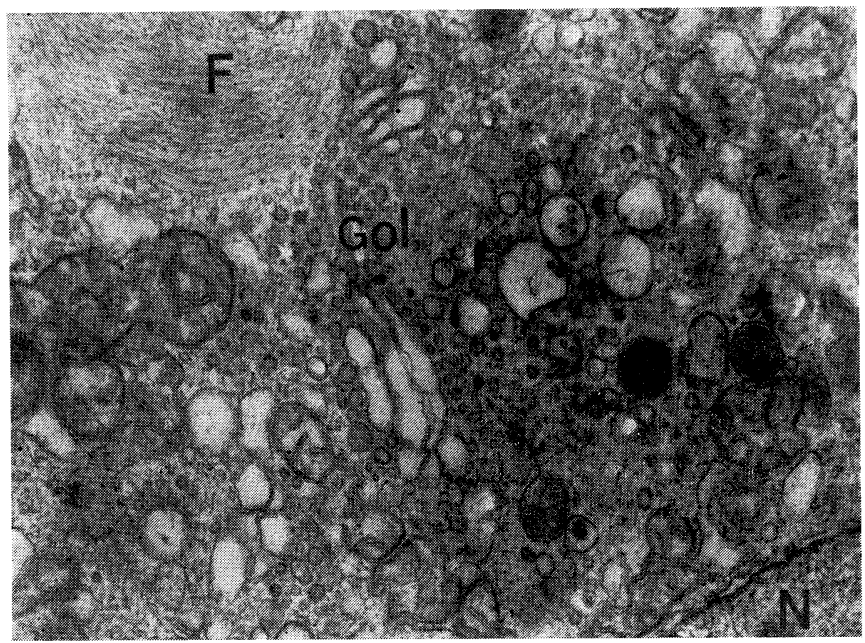

Fig. 8. Electron micrograph of a portion of an active beta cell (3 days high carbohydrate feeding after 11 days starvation) showing well developed Golgi area witn premature granules. Gols : Golgi apparatus, $\mathrm{P}$ : premature granules, G : granule, M : mitochondria $\times 36,000$

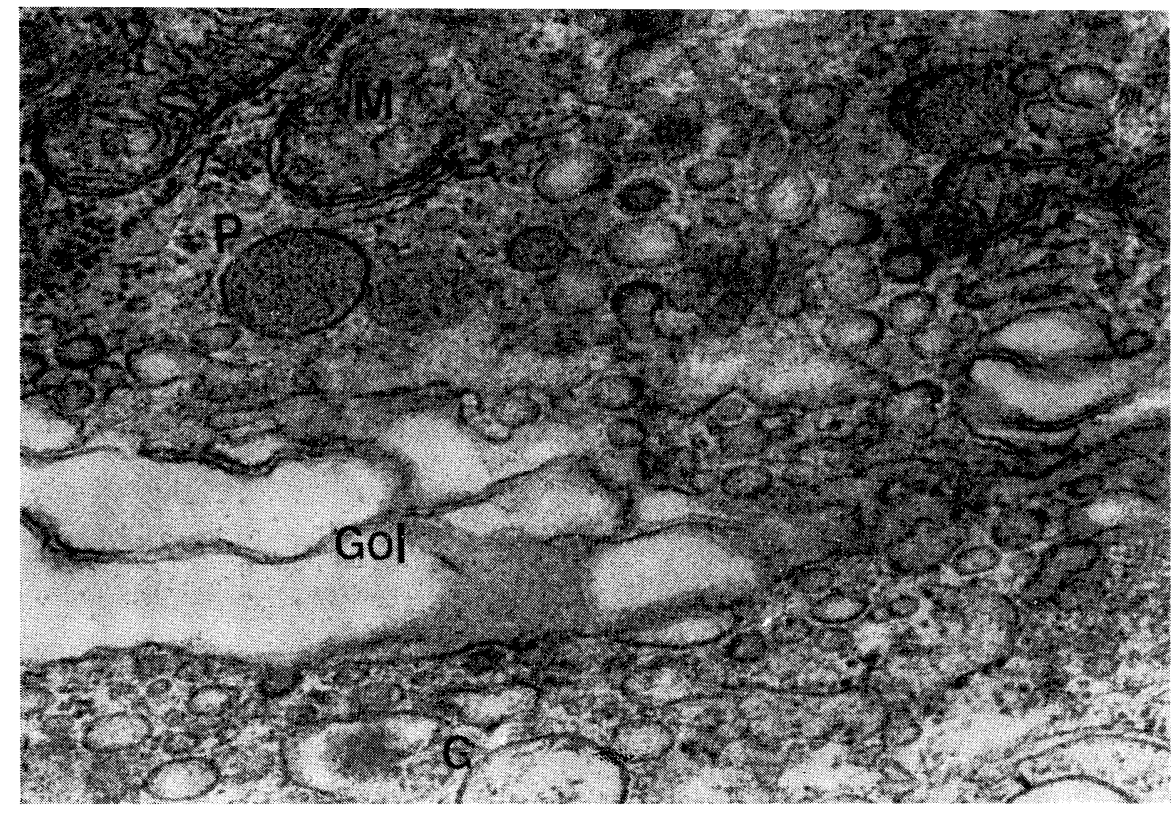

